\title{
Acidianus sulfidivorans sp. nov., an extremely acidophilic, thermophilic archaeon isolated from a solfatara on Lihir Island, Papua New Guinea, and emendation of the genus description
}

\author{
Correspondence \\ Jason J. Plumb \\ jason.plumb@csiro.au
}

\author{
Jason J. Plumb, ${ }^{1}$ Christina M. Haddad, ${ }^{1}$ John A. E. Gibson ${ }^{2,3}$ \\ and Peter D. Franzmann ${ }^{1}$ \\ ${ }^{1}$ Centre for Environment and Life Sciences, CSIRO Land and Water, Private Bag No. 5, \\ Wembley, Western Australia 6913, Australia \\ ${ }^{2} \mathrm{CSIRO}$ Marine and Atmospheric Research, GPO Box 1538, Hobart, Tasmania, 7001, Australia \\ ${ }^{3}$ School of Zoology, University of Tasmania, Private Bag 5, Hobart, Tasmania 7001, Australia
}

The genus Acidianus, which was first described by Segerer et al. (1986), is a member of the order Sulfolobales (Stetter, 1989), and comprises three formally recognized species of facultatively aerobic thermoacidophiles isolated from geothermal or hydrothermal systems. The phylogenetically similar species Acidianus infernus and Acidianus ambivalens and the more distantly related and less thermophilic species Acidianus brierleyi (Fuchs et al., 1996), originally named Sulfolobus brierleyi (Brierley \& Brierley, 1973; Zillig et al., 1980), grow as facultative aerobes with the ability to oxidize or reduce elemental sulfur depending on the available oxygen supply and are capable of autotrophic growth. Two recently described species, 'Acidianus tengchongensis' and 'Acidianus manzaensis', have extended the genotypic and phenotypic diversity within the genus (He et al., 2004; Yoshida et al., 2006).

Abbreviation: GDGTs, glycerol dialkyl glycerol tetraethers.

The GenBank/EMBL/DDBJ accession number for the 16S rRNA gene sequence of strain $\mathrm{JP}^{\top}{ }^{\top}$ is AY907891.
Moist, sulfur-rich soil was collected from the hot $\left(>80^{\circ} \mathrm{C}\right)$ and acidic $(\mathrm{pH} \sim 2)$ edge of a hot spring within a solfatara on the geothermally active island of Lihir in Papua New Guinea. Sample material was stored for 3 days without temperature control during transfer to the laboratory. Microbial enrichments were performed in 250-ml Erlenmeyer flasks with $70 \mathrm{ml}$ basal medium (Plumb et al., 2002), which contained (per litre) $1.5 \mathrm{~g}\left(\mathrm{NH}_{4}\right)_{2} \mathrm{SO}_{4}, 0.25 \mathrm{~g}$ $\mathrm{KH}_{2} \mathrm{PO}_{4}, 0.25 \mathrm{~g} \mathrm{MgSO}_{4} .7 \mathrm{H}_{2} \mathrm{O}$ and $0.1 \mathrm{~g}$ yeast extract, adjusted to $\mathrm{pH} 0.8$ with $18 \mathrm{M} \mathrm{H}_{2} \mathrm{SO}_{4}$, supplemented with $1 \%(\mathrm{w} / \mathrm{v})$ chalcopyrite concentrate $\left(88 \% \mathrm{CuFeS}_{2}, 4 \% \mathrm{FeS}_{2}\right.$ and trace quantities of $\mathrm{SiO}_{2}, \mathrm{FeS}$ and clinichlore) with a mean particle size of $37.5 \mu \mathrm{m}\left(\mathrm{P}_{80}=85 \mu \mathrm{m}\right)$ and $1 \%(\mathrm{w} / \mathrm{v})$ sulfidic ore material collected from Lihir. Enrichment cultures were incubated at $72{ }^{\circ} \mathrm{C}$ in a shaker incubator at 150 r.p.m. After incubation for 1 week, abundant growth of small, irregular-shaped cocci was detected by using a phase-contrast microscope (Leitz Diaplan). The enrichment culture was subcultured into fresh medium of the same composition once and then maintained on growth medium 
with $1 \%(\mathrm{w} / \mathrm{v})$ chalcopyrite concentrate as the energy source. A pure strain, designated $\mathrm{JP}^{\mathrm{T}}$, was isolated by using serial decimal dilutions to extinction in shake flasks of basal medium at $\mathrm{pH} 0.8$ supplemented with $1 \%(\mathrm{w} / \mathrm{v})$ chalcopyrite concentrate. Strain $\mathrm{JP7}^{\mathrm{T}}$ was maintained routinely in shake flasks with this medium and the incubation conditions given above. Unless specified otherwise, strain $\mathrm{JP}^{\mathrm{T}}$ was grown in basal medium at $\mathrm{pH}$ 0.8. Cell morphology was similar to other members of the order Sulfolobales, with slightly aspherical shape, and occasional planar sides and edges. Cells occurred singly or occasionally in pairs, the latter particularly during the exponential growth phase. On all growth media, cells ranged between 0.5 and $1.5 \mu \mathrm{m}$ in diameter and were non-motile. Cells of strain $\mathrm{JP7}^{\mathrm{T}}$ stained Gram-negative.

Energy sources for growth of strain $\mathrm{JP}^{\mathrm{T}}$ were tested in shake flask culture incubated aerobically using the basal medium described above. Chemically defined inorganic substrates tested were elemental sulfur $\left(5 \mathrm{~g} \mathrm{l}^{-1}\right)$ and $\mathrm{FeSO}_{4} \cdot 7 \mathrm{H}_{2} \mathrm{O}$ $\left(10 \mathrm{~g} \mathrm{l}^{-1}\right)$. A stock solution of $\mathrm{FeSO}_{4} \cdot 7 \mathrm{H}_{2} \mathrm{O}$ was sterilized by filtration through a $0.2-\mu \mathrm{m}$ pore size filter. Elemental sulfur was sterilized by heating at $100^{\circ} \mathrm{C}$ for $1 \mathrm{~h}$, which was repeated twice on consecutive days. The concentration of $\mathrm{Fe}^{2+}$ was determined spectrophotometrically (Wilson, 1960). Growth on elemental sulfur was determined by phase-contrast microscopy and by measuring total solution sulfur concentration by using inductively coupled plasma optical emission spectroscopy. Although specific detection of sulfate was not performed, it was assumed that elemental sulfur was oxidized completely to sulfate as the $\mathrm{pH}$ of the medium decreased significantly, presumably because of production of sulfuric acid. Strain $\mathrm{JP7}^{\mathrm{T}}$ grew successfully using $\mathrm{Fe}^{2+}$ or sulfur as an energy source, although to lower cell density than growth on chalcopyrite concentrate. Strain $\mathrm{JP7}^{\mathrm{T}}$ oxidized $\mathrm{Fe}^{2+}$ rapidly compared with uninoculated controls; however, growth using $\mathrm{Fe}^{2+}$ as the sole energy source was not sustained in subsequent subcultures without the addition of elemental sulfur or mineral sulfide or other reduced sulfur compounds. Complex mineral sulfides were also tested as energy sources for growth of strain $\mathrm{JP}^{\mathrm{T}}$. These tests were conducted in shake flasks containing basal medium at $\mathrm{pH}$ 0.8. Mineral sulfides tested included pyrite $(1 \%, \mathrm{w} / \mathrm{v})$, chalcopyrite and arsenopyrite $(1-10 \%, \mathrm{w} / \mathrm{v})$, which were added as sterilized, finely ground concentrates or finely ground massive sulfides. Growth was monitored with a phase-contrast microscope over three subsequent subcultures where possible. Strain $\mathrm{JP7}^{\mathrm{T}}$ grew well on all three mineral sulfide substrates and maintained good growth over numerous subcultures on chalcopyrite and arsenopyrite up to a loading of $10 \%(\mathrm{w} / \mathrm{v})$. Growth was also observed on chalcopyrite and pyrite in basal medium prepared without yeast extract at $\mathrm{pH} 0.8$ over subsequent subcultures, with a cell density of $10^{8}$ cells $\mathrm{ml}^{-1}$ achieved after 5-7 days incubation. A significantly higher growth rate on chalcopyrite was achieved when the growth medium contained yeast extract, with a cell density of $10^{8}$ cells $\mathrm{ml}^{-1}$ achieved after 3 days incubation. These results suggested that strain
$\mathrm{JP7}^{\mathrm{T}}$ is a facultative autotroph, although confirmation of this via uptake of radio-labelled carbon was not performed. Optimal growth was achieved in medium containing $\mathrm{NaCl}$ up to a concentration of $0.5 \%(\mathrm{w} / \mathrm{v})$. No growth occurred in medium containing $\mathrm{NaCl}$ at a concentration of $1 \%(\mathrm{w} / \mathrm{v})$. Strain $\mathrm{JP7}^{\mathrm{T}}$ was less halotolerant than previously described species of the genus Acidianus, which are able to grow in medium containing up to $4 \%(\mathrm{w} / \mathrm{v}) \mathrm{NaCl}$ (Segerer et al., 1986).

Growth of strain JP7 ${ }^{\mathrm{T}}$ under anaerobic conditions was tested by using $\mathrm{H}_{2}$ or $\mathrm{H}_{2} \mathrm{~S}\left(\mathrm{Na}_{2} \mathrm{~S} .9 \mathrm{H}_{2} \mathrm{O}\right.$ added at $\left.2 \mathrm{~g} \mathrm{l}^{-1}\right)$ as an electron donor and elemental sulfur or ferric iron $\left[\mathrm{Fe}_{2}\left(\mathrm{SO}_{4}\right)_{3}\right.$ at $10 \mathrm{~g} \mathrm{l}^{-1}$ ] as a terminal electron acceptor. A. infernus DSM $3191^{\mathrm{T}}$, A. ambivalens DSM $3772^{\mathrm{T}}$ and A. brierleyi DSM $1651^{\mathrm{T}}$ were included as reference strains in anaerobic growth tests. The media and growth conditions used were as described by Segerer et al. (1986) except that no sodium sulfide was added to the anaerobic media. All cultures showing growth were subcultured twice for confirmation of growth. A. infernus DSM $3191^{\mathrm{T}}$ and A. ambivalens DSM $3772^{\mathrm{T}}$ grew by oxidizing $\mathrm{H}_{2}$ and by reducing elemental sulfur to $\mathrm{H}_{2} \mathrm{~S}$ as expected. A. brierleyi DSM $1651^{\mathrm{T}}$ and strain $\mathrm{JP7}^{\mathrm{T}}$ did not grow by oxidizing $\mathrm{H}_{2}$ or by reducing elemental sulfur. $A$. brierleyi has previously been reported to grow by oxidizing $\mathrm{H}_{2}$ and by reducing elemental sulfur (Segerer et al., 1986), although, as discussed below, interpretation of this result is difficult owing to the addition of sodium sulfide $\left(0.75 \mathrm{~g} \mathrm{l}^{-1}\right)$ to the anaerobic growth medium. Strain $\mathrm{JP}^{\mathrm{T}}$ and A. brierleyi grew by oxidizing $\mathrm{H}_{2} \mathrm{~S}$ and by reducing ferric iron (Fig. 1) both with and without the addition of organic carbon. Strain $\mathrm{JP7}^{\mathrm{T}}$ and A. brierleyi DSM $1651^{\mathrm{T}}$ grew when sodium sulfide was added at $0.75 \mathrm{~g} \mathrm{l}^{-1}$, the concentration used in the anaerobic media prepared by Segerer et al. (1986). This result suggests that the previously reported growth by $A$.

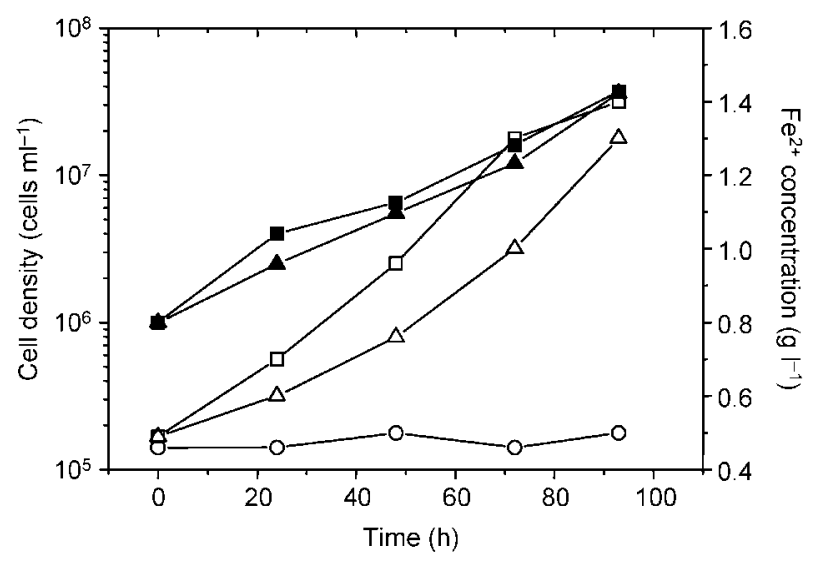

Fig. 1. Cell densities (solid symbols) and ferrous iron concentration (open symbols) for growth of strain $\mathrm{JP}^{\top}$ (triangles) and A. brierleyi DSM $1651^{\top}$ (squares) in anaerobic medium by oxidation of $\mathrm{H}_{2} \mathrm{~S}$ and reduction of ferric iron. Reduction of ferric iron to ferrous iron in an uninoculated control (open circles) is also shown. No cells were detected in the uninoculated control. 
brierleyi with $\mathrm{H}_{2}$ as an energy source may have been due to the oxidation of $\mathrm{H}_{2} \mathrm{~S}$ produced as a result of the addition of sodium sulfide to the anaerobic medium. A. infernus DSM $3191^{\mathrm{T}}$ and A. ambivalens DSM $3772^{\mathrm{T}}$ did not grow via this redox couple. None of the four strains grew in anaerobic medium by oxidizing $\mathrm{H}_{2}$ and reducing ferric iron, in contrast to the results for ' $A$. manzaensis' (Yoshida et al., 2006). Brock \& Gustafson (1976) showed that Sulfolobus acidocaldarius grew by oxidizing elemental sulfur or glutamate and by reducing ferric iron and, more recently, ' $A$. manzaensis' was shown to be able to grow by oxidizing elemental sulfur or $\mathrm{H}_{2}$ and by reducing ferric iron (Yoshida et al., 2006). A. brierleyi and A. infernus grew by oxidizing elemental sulfur using molybdate as a terminal electron acceptor (Segerer et al., 1986). All four tested strains grew in anaerobic medium by oxidizing $\mathrm{H}_{2} \mathrm{~S}$ and by reducing elemental sulfur. The inability of strain $\mathrm{JP}^{\mathrm{T}}$ to oxidize $\mathrm{H}_{2}$ under sulfur-reducing or ferric-iron-reducing conditions suggests that this strain lacks the hydrogenase used by A. ambivalens for this metabolism (Laska et al., 2003). A number of studies have identified the enzyme systems responsible for aerobic and anaerobic metabolism in $A$. ambivalens (reviewed by Kletzin et al., 2004). More work is needed to characterize the mechanisms for anaerobic growth of other species of the genus Acidianus.

Aerobic organotrophic growth by strain $\mathrm{JP}^{\mathrm{T}}$ was tested by using glucose, sucrose, cellobiose, gelatin, yeast extract, meat extract and tryptone (each at $1 \mathrm{~g} \mathrm{l}^{-1}$ ), each provided separately as the sole energy source. Cell growth was monitored by phase-contrast microscopy. Basal medium containing $0.1 \mathrm{~g}$ yeast extract $l^{-1}$ at $\mathrm{pH} 0.8$ was used to provide a source of micronutrients, carbon or other growth requirements for testing of organic substrates. Strain $\mathrm{JP}^{\mathrm{T}}$ was unable to grow using any of the organic substrates as a sole energy source.

The temperature range for growth of strain $\mathrm{JP}^{\mathrm{T}}$ was determined via a temperature gradient incubator (Terratec Asia Pacific) and by application of the Ratkowsky equation (Ratkowsky et al., 1983; Plumb et al., 2002; Franzmann et al., 2005). For this test, strain $\mathrm{JP7}^{\mathrm{T}}$ was grown in a mineralsulfide-free medium that enabled non-destructive turbidimetric measurement of growth. The medium contained (per litre) $0.4 \mathrm{~g} \mathrm{MgSO}_{4} .7 \mathrm{H}_{2} \mathrm{O}, 0.4 \mathrm{~g}\left(\mathrm{NH}_{4}\right)_{2} \mathrm{SO}_{4}, 0.4 \mathrm{~g} \mathrm{KH}_{2} \mathrm{PO}_{4}$, $4.0 \mathrm{~g} \mathrm{~K}_{2} \mathrm{~S}_{4} \mathrm{O}_{6}, 20.0 \mathrm{~g} \mathrm{FeSO}_{4} .7 \mathrm{H}_{2} \mathrm{O}$ and $1.0 \mathrm{~g}$ meat extract, with $\mathrm{pH}$ adjusted to 0.8 with $18 \mathrm{M} \mathrm{H}_{2} \mathrm{SO}_{4}$. The potassium tetrathionate, ferrous sulfate and meat extract were added as filter-sterilized solutions to the basal medium after sterilization by autoclaving at $121^{\circ} \mathrm{C}$ for $20 \mathrm{~min}$. Biomass in cultures grown at 24 different temperatures ranging from 40 to $85^{\circ} \mathrm{C}$ was quantified by measuring the optical density at $550 \mathrm{~nm}$. The square root of the inverse of the time taken to reach an optical density of 0.25 at each temperature was plotted against temperature and the plot was fitted by using the Ratkowsky equation. Extrapolated minimum, optimum and maximum temperatures for growth were $45.2 \pm 1.3$, $74.4 \pm 0.7$ and $82.5 \pm 0.8^{\circ} \mathrm{C}$, respectively. At the temperature closest to the extrapolated optimum at which strain $\mathrm{JP7}^{\mathrm{T}}$ was grown $\left(72.9^{\circ} \mathrm{C}\right)$, the generation time of strain $\mathrm{JP}^{\mathrm{T}}$ in this mixotrophic medium was $8.4 \mathrm{~h}$. Strain $\mathrm{JP7}^{\mathrm{T}}$ was not as thermophilic as $A$. infernus or A. ambivalens, which grew optimally at 90 and $80^{\circ} \mathrm{C}$, respectively (Segerer et al., 1986; Zillig et al., 1986), but was more thermophilic than $A$. brierleyi, which grew optimally at $70{ }^{\circ} \mathrm{C}$ (Segerer et al., 1986).

The $\mathrm{pH}$ range for growth of strain $\mathrm{JP}^{\mathrm{T}}$ was determined by using two different approaches. Growth at different $\mathrm{pH}$ was tested with either basal medium containing chalcopyrite concentrate $(1 \%, \mathrm{w} / \mathrm{v})$ or basal medium supplemented with $\mathrm{FeSO}_{4} .7 \mathrm{H}_{2} \mathrm{O}\left(10 \mathrm{~g} \mathrm{l}^{-1}\right)$. The $\mathrm{pH}$ of the medium was adjusted by using concentrated $\mathrm{H}_{2} \mathrm{SO}_{4}$. All $\mathrm{pH}$ measurements were made at room temperature by using a SenTix HW electrode and a $\mathrm{pH}$ 330i meter (WTW). Standard solutions of $\mathrm{pH} 2.0$ and $\mathrm{pH} 1.0$ buffer (Merck) were used for calibration and to test the accuracy of low $\mathrm{pH}$ readings. Inoculated and uninoculated control flasks were set up in duplicate. As stated above, strain $\mathrm{JP}^{\mathrm{T}}$ required a small amount of sulfur or mineral sulfide in the growth medium in order to maintain successful growth over repeated subcultures; however, the inclusion of sulfur or mineral sulfide causes significant changes in $\mathrm{pH}$ of the medium owing either to acid production via sulfur oxidation or to acid consumption via mineral sulfide oxidation, and the resulting change in $\mathrm{pH}$ makes assessment of the $\mathrm{pH}$ range for growth difficult. In order to minimize changes in $\mathrm{pH}$ of the medium due to addition of sulfur or mineral sulfide, the effect of $\mathrm{pH}$ on the growth of strain $\mathrm{JP}^{\mathrm{T}}$ was tested in basal medium containing $\mathrm{Fe}^{2+}$ as the sole energy source. Inoculum was prepared by growing strain $\mathrm{JP}^{\mathrm{T}}$ in basal medium at $\mathrm{pH} 0.8$ or 1.8 with chalcopyrite concentrate $(1 \%, \mathrm{w} / \mathrm{v})$. All flasks were incubated in a shaker operated at $\sim 72{ }^{\circ} \mathrm{C}$, with shaking at 150 r.p.m. Cultures grown on chalcopyrite were monitored by using a Helber counting chamber and phase-contrast microscopy. In cultures grown on ferrous sulfate, oxidation of $\mathrm{Fe}^{2+}$ was monitored by measuring the $\mathrm{Fe}^{2+}$ concentration spectrophotometrically (Wilson, 1960). Strain JP7 ${ }^{\mathrm{T}}$ grew and oxidized $\mathrm{Fe}^{2+}$ over a broad range of $\mathrm{pH}$. At the extremes of the $\mathrm{pH}$ range tested $\left(\mathrm{pH} 0.4\right.$ and 3.0) strain $\mathrm{JP7}^{\mathrm{T}}$ oxidized the least $\mathrm{Fe}^{2+}$ (Fig. 2a). Strain $\mathrm{JP}^{\mathrm{T}}$ oxidized $\mathrm{Fe}^{2+}$ at a similar rate at $\mathrm{pH} 0.8,1.0$ and 1.4, although a slight lag prior to achieving the maximum oxidation rate was observed at $\mathrm{pH} 0.8$ and 1.0. Slower rates of $\mathrm{Fe}^{2+}$ oxidation were observed at other test $\mathrm{pH}$ values, but rates of $\mathrm{Fe}^{2+}$ oxidation at these $\mathrm{pH}$ values were greater than occurred in the uninoculated controls. Growth on chalcopyrite concentrate was observed at all $\mathrm{pH}$ values tested up to a $\mathrm{pH}$ of 2.2. A comparison of the growth of strain $\mathrm{JP}^{\mathrm{T}}$ on chalcopyrite over a range from $\mathrm{pH} 0.4$ to 1.0 was made (Fig. $2 \mathrm{~b}$ ). At such a low $\mathrm{pH}$, acid production or consumption by the mineral sulfide does not change $\mathrm{pH}$ effectively. Growth at $\mathrm{pH} 0.4,0.6$ and 0.8 occurred after an initial lag period; however, the growth rate and maximum cell density achieved at $\mathrm{pH} 0.8$ and 1.0 were almost identical. In another test, cell growth was maintained over numerous subcultures in basal medium with chalcopyrite $(1 \%, \mathrm{w} / \mathrm{v})$ at $\mathrm{pH} 0.35$. At this extremely low $\mathrm{pH}$, cells remained intact but were 

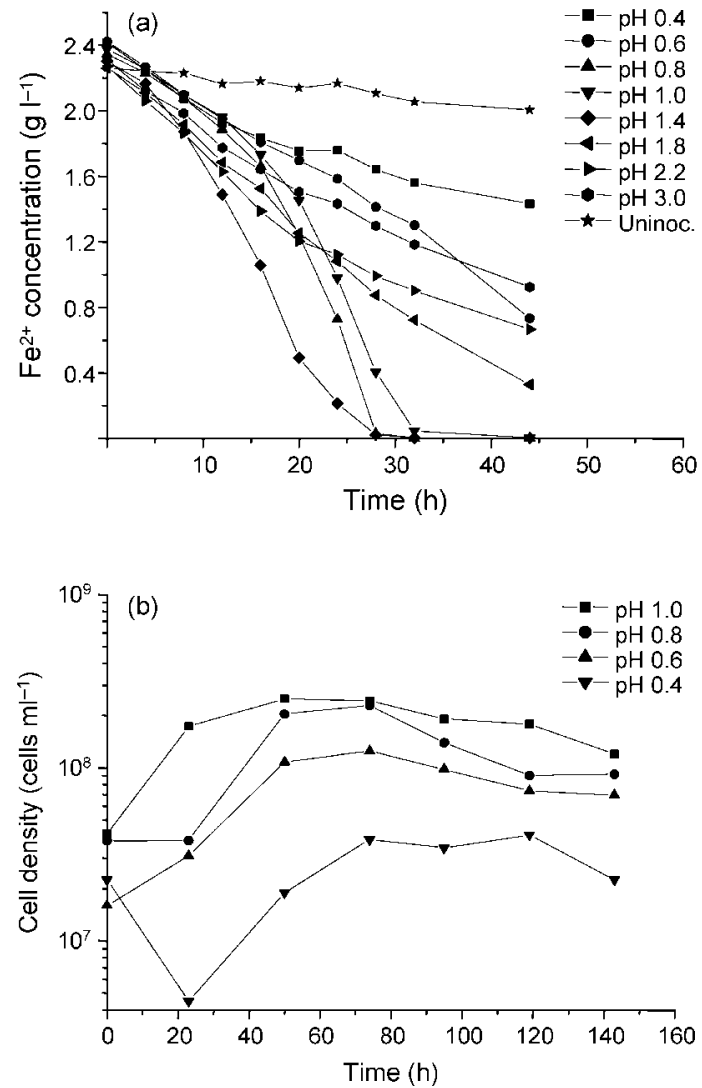

Fig. 2. Plot showing the relationship between growth and $\mathrm{pH}$ for strain $\mathrm{JP} 7^{\top}$ based on oxidation of $\mathrm{Fe}^{2+}$ (a) and growth on chalcopyrite concentrate (b). Uninoc., Uninoculated.

smaller in size and slightly refractile in appearance, probably because of their stressed condition. The $\mathrm{pH}$ range for growth of strain $\mathrm{JP}^{\mathrm{T}}$ extended to significantly lower values than for other species of Acidianus. According to Segerer et al. (1986) and Zillig et al. (1986), the lower $\mathrm{pH}$ limit for growth of A. infernus, A. ambivalens and A. brierleyi was $\mathrm{pH} 1.0$, with optimal growth occurring between $\mathrm{pH} 1.5$ and 2.0.

The 16S rRNA gene was amplified from cells of strain JP7 ${ }^{\mathrm{T}}$ by using direct lysis PCR with primers 25Fa (5'-TCYGGTTGATCCYGCCRG-3') and 1492R (5'-ACGGITACCTTGTTACGACTT-3'). A $1 \mathrm{ml}$ sample of culture was centrifuged at $12000 \mathrm{~g}$ for $8 \mathrm{~min}$ to pellet the cells. Pelleted cells were resuspended in $1 \mathrm{ml} \mathrm{PBS} \mathrm{(pH} \mathrm{7.2)} \mathrm{and}$ $1 \mu \mathrm{l}$ of this solution was then used as template for PCR by using the HotstartTaq Master Mix (Qiagen). The PCR products were purified with the UltraClean PCR Clean-up kit (MO BIO Laboratories Inc.) and both strands were sequenced by using the BigDye Terminator version 3.1 cycle-sequencing kit (Applied Biosystems) and primers 25Fa, 530Fa (5'-GTGTCAGCCGCCGCGG-3'), 934Fa (5' AGGAATTGGCGGGGGAGCAG-3'), 519R (5' -TTACCGCGGCGGCTG-3'), 915R (5'-GTGCTCCCCCGCCAATTCCT- $3^{\prime}$ ) and 1492R. A near-complete 16S rRNA gene contiguous sequence (1473 bases) was assembled by using
Chromas Pro (Technelysium) and then compared with sequence data in the GenBank database via BLAST (Altschul et al., 1997) available at http://www.ncbi.nlm.nih.gov. The sequence was then aligned against reference sequences of species of Acidianus by using the program ARB (Ludwig et al., 2004). A phylogenetic tree was constructed by using distance matrix calculations and the neighbour-joining method (Saitou \& Nei, 1987) available in the ARB program. The stability of tree nodes was evaluated by using bootstrap resampling (Felsenstein, 1985). Construction of a similarity matrix was performed also within ARB by using representative sequences from the Sulfolobales. The 16S rRNA gene sequence of strain $\mathrm{JP7}^{\mathrm{T}}$ was most closely related to that of 'A. manzaensis' NA-1, with a similarity of $97.2 \%$. The $16 \mathrm{~S}$ rRNA gene sequences of $A$. ambivalens DSM $3772^{\mathrm{T}}, A$. infernus DSM $3191^{\mathrm{T}}$ and A. brierleyi DSM $1651^{\mathrm{T}}$ shared similarity of $92.6,92.3$ and $91.2 \%$, respectively, with that of strain $\mathrm{JP7}^{\mathrm{T}}$. On the basis of $16 \mathrm{~S}$ rRNA gene sequence analysis, there is probably some doubt as to whether $A$. brierleyi should be included in the genus Acidianus, although it shares many phenotypic similarities with other members of this genus. Similarity of the $16 \mathrm{~S}$ rRNA gene sequence of strain $\mathrm{JP7}^{\mathrm{T}}$ to those of the type strains of two other representatives of the Sulfolobaceae, Metallosphaera prunae and Sulfolobus solfataricus, was 90 and $87.7 \%$, respectively. A phylogenetic tree generated from 16S rRNA gene sequence data from members of the Sulfolobales (Fig. 3) shows strain $\mathrm{JP7}^{\mathrm{T}}$ clustering with 'A. manzaensis'. The positioning of strain $\mathrm{JP}^{\mathrm{T}}$ with other species of the genus Acidianus was well supported according to bootstrap analysis.

Genomic DNA for the determination of base composition was extracted from a late-exponential phase culture according to the method of Plumb et al. (2001), but without the use of the bead-beating step. The DNA was purified by using the UltraClean PCR Clean-up kit (MO BIO Laboratories Inc.). Agarose gel electrophoresis was used to confirm the extraction of high-molecular-mass genomic DNA. The DNA was hydrolysed with P1 nuclease and the nucleotides were dephosphorylated with bovine alkaline phosphatase (Mesbah et al., 1989). The G $+\mathrm{C}$ content was determined by analysing the resultant deoxyribonucleosides by HPLC (Shimadzu Corp.). The column used for analysis was a VYDAC 201SP54 $\left(\mathrm{C}_{18}, 5 \mu \mathrm{m}, 250 \times 4.6 \mathrm{~mm}\right)$ equipped with a 201GD54H guard column (Vydac). The DNA G+C content of strain JP7 ${ }^{\mathrm{T}}$ was $31.1 \mathrm{~mol} \%$, which is close to that of $A$. ambivalens (31 mol\%), A. infernus (32.7 mol\%) and $A$. brierleyi (31.5 mol\%) (Segerer et al., 1986; Zillig et al., 1986).

Freeze-dried biomass collected from cultures of strain $\mathrm{JP}^{\mathrm{T}}$ was used to characterize the cell membrane phospholipids. Biomass was placed in a thick-walled test tube along with $3 \mathrm{ml}$ of a mixture containing 10:1:1 methanol/ $\mathrm{CHCl}_{3} /$ concentrated $\mathrm{HCl}$. The test tube was capped and the mixture was heated overnight at $95^{\circ} \mathrm{C}$ in a water bath. After cooling, $1 \mathrm{ml}$ water was added and the reaction mixture was extracted three times with $1.8 \mathrm{ml}$ portions of a $4: 1$ mixture of $\mathrm{n}$-hexane and $\mathrm{CH}_{2} \mathrm{Cl}_{2}$. The extracts were pooled and the 


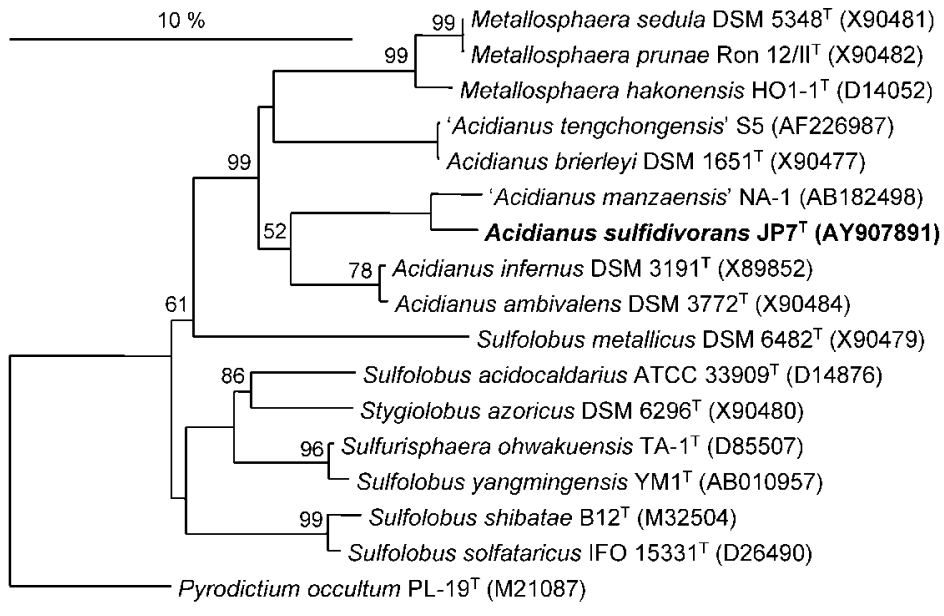

Fig. 3. Phylogenetic tree based on $16 \mathrm{~S}$ rRNA gene sequence data generated by using distance matrix and neighbour-joining methods for selected members of the Sulfolobales (GenBank accession numbers are given in parentheses) showing the affiliation of strain $\mathrm{JP}^{\top}$ with members of the genus Acidianus. Bootstrap values are percentages based on 1000 resamplings. Bar, $10 \%$ sequence divergence.

solvent was removed under a stream of $\mathrm{N}_{2}$. The ether lipids were stored at $-20^{\circ} \mathrm{C}$. Gas chromatographic analysis was carried out by using a Hewlett Packard 5890 gas chromatograph equipped with an on-column auto-injector and a flame-ionization detector that was maintained at $405^{\circ} \mathrm{C}$. The capillary column used was a $2.5-\mathrm{m}$ polyimide-clad SGE HT5, with an internal diameter of $0.25 \mathrm{~mm}$ and a film thickness of $0.1 \mu \mathrm{m}$ (SGE International). Samples were injected with the injector and column at $30^{\circ} \mathrm{C}$. The oven temperature was maintained for $2 \mathrm{~min}$, then increased at $35^{\circ} \mathrm{C} \mathrm{min}{ }^{-1}$ to $350{ }^{\circ} \mathrm{C}$ and then at $5{ }^{\circ} \mathrm{C} \mathrm{min}^{-1}$ to $400{ }^{\circ} \mathrm{C}$. At the end of the run, the oven was cooled at a rate of $30^{\circ} \mathrm{C}$ $\mathrm{min}^{-1}$ in order to reduce the likelihood of column damage as a result of rapid temperature change. The carrier gas was helium and the head pressure was $35 \mathrm{kPa}$. The ether lipids eluted as well-separated peaks. The concentrations of glycerol dialkyl glycerol tetraethers (GDGTs) and glycerol dialkyl calditol tetraethers (calditols) were determined. Analysis of the ether lipids in strain $\mathrm{JP7}^{\mathrm{T}}$ showed an almost $50: 50$ split between GDGTs and calditols. Cyclized forms of each of these tetraethers with one to eight mid-chain cyclopentyl rings were detected, with the majority of tetraethers containing six rings. Although the distribution of cyclized tetraether lipids varies according to factors such as temperature and $\mathrm{pH}$, this ether lipid profile was consistent with profiles of members of the Sulfolobales grown at high temperature (De Rosa et al., 1983).

The phenotypic and genotypic characteristics described above suggest that strain $\mathrm{JP}^{\mathrm{T}}$ is a member of the genus Acidianus. Differences in $16 \mathrm{~S}$ rRNA gene sequence, aerobic and anaerobic growth, temperature range for growth and $\mathrm{pH}$ range for growth justify the conclusion that strain $\mathrm{JP7}^{\mathrm{T}}$ represents a novel species of the genus Acidianus. The name Acidianus sulfidivorans sp. nov. is proposed for this novel species.

\section{Emended description of Acidianus Segerer et al. 1986}

Cells are Gram-negative and occur singly or occasionally in pairs during exponential growth; the cells have an irregular coccoid morphology (sometimes lobed or showing sharp bends, and resembling tetrahedrons, pyramids, discs or dishes). Cells are non-motile. Cell width is between 0.5 and $2 \mu \mathrm{m}$, depending on culture conditions. A surrounding envelope about $25 \mathrm{~nm}$ wide covering the cell membrane is evident in thin section. The envelope is composed of subunits in a hexagonal array. The cells are facultative aerobes. Lithotrophic growth occurs aerobically by means of $S^{0}$ oxidation, mineral sulfide oxidation or $\mathrm{Fe}^{2+}$ oxidation. Anaerobic growth occurs by means of $S^{0}$ or ferric iron reduction with $\mathrm{H}_{2}$ or $\mathrm{H}_{2} \mathrm{~S}$. The cells are autotrophic and mixotrophic and may grow organotrophically on yeast extract without $\mathrm{S}^{0}$ in the presence of $\mathrm{O}_{2}$. The organisms are thermoacidophiles, thriving between $\mathrm{pH} 0.35$ and 6 and between 45 and $96{ }^{\circ} \mathrm{C}$. They grow in the presence of $0.1 \%$ $\mathrm{NaCl}$ and may grow in media containing up to $4 \% \mathrm{NaCl}$. Neither muramic acid nor meso-diaminopimelic acid is present, indicating the absence of murein. Elongation factor 2 is sensitive to adenosine diphosphate ribosylation by diphtheria toxin. Cells contain isopranyl ether lipids, which consist of GDGTs and calditols, including lipids with mid-chain cyclopentyl rings, and also caldariellaquinone. Members of the genus are resistant to vancomycin, ampicillin and kanamycin $\left(150 \mu \mathrm{g} \mathrm{ml}^{-1}\right.$ each). DNAdependent RNA polymerase shows incomplete immunological cross-reactions with antibody against DNAdependent RNA polymerase from Sulfolobus acidocaldarius DSM $639^{\mathrm{T}}$. The purified DNA has a G $+\mathrm{C}$ content of 31$33 \mathrm{~mol} \%$. Members of the genus occur in acidic solfataras and in marine hydrothermal systems. The type species is Acidianus infernus.

\section{Description of Acidianus sulfidivorans sp. nov.}

Acidianus sulfidivorans (sul.fi.di.vo'rans. N.L. n. sulfidum sulfide; L. part. adj. vorans devouring; N.L. part. adj. sulfidivorans sulfide-devouring).

Displays the following properties in addition to those given in the emended genus description. Cells are $0.5-1.5 \mu \mathrm{m}$ in diameter. Growth is obligately chemolithotrophic. Good 
growth occurs under aerobic conditions on elemental sulfur, ferrous iron, pyrite and other mineral sulfides. Under anaerobic conditions, ferric iron or elemental sulfur serve as the terminal electron acceptor for growth via oxidation of $\mathrm{H}_{2} \mathrm{~S}$. Cells do not grow using elemental sulfur as a terminal electron acceptor for oxidation of $\mathrm{H}_{2}$. Cells are facultatively autotrophic, as they grow when provided with $\mathrm{CO}_{2}$ as the sole source of carbon and heterotrophically using yeast extract or meat extract as a carbon source. Cells do not grow organotrophically. Cells grow over a range of temperatures from 45 to $83^{\circ} \mathrm{C}$, with optimum growth at $74{ }^{\circ} \mathrm{C}$. The $\mathrm{pH}$ range for growth is $0.35-3.0$, with optimal growth at $\mathrm{pH} 0.8-1.4$. Optimal growth occurs at up to $0.5 \%(\mathrm{w} / \mathrm{v})$ $\mathrm{NaCl}$. The DNA G+C content is $31.1 \mathrm{~mol} \%$. Cellmembrane lipids consist of a mixture of GDGTs and glycerol dialkyl calditol tetraethers, most of which are cyclized tetraethers.

The type strain, $\mathrm{JP}^{\mathrm{T}}\left(=\mathrm{DSM} 18786^{\mathrm{T}}=\mathrm{JCM} 13667^{\mathrm{T}}\right)$, was isolated from the sulfur-rich acidic edge of a solfataric hot spring.

\section{Acknowledgements}

We are grateful to the government of Papua New Guinea for granting access to the biodiversity of Papua New Guinea, to BHP Billiton for providing financial assistance for some of the work and to Professor Hans Trüper for assisting with the nomenclature.

\section{References}

Altschul, S. F., Madden, T. L., Schaffer, A. A., Zhang, J., Zhang, Z., Miller, W. \& Lipman, D. J. (1997). Gapped BLAST and PSI-BLAST: a new generation of protein database search programs. Nucleic Acids Res $\mathbf{2 5}$, 3389-3402.

Brierley, C. L. \& Brierley, J. A. (1973). A chemolithoautotrophic and thermophilic microorganism isolated from an acidic hot spring. Can J Microbiol 19, 183-188.

Brock, T. D. \& Gustafson, J. (1976). Ferric iron reduction by sulfurand iron-oxidizing bacteria. Appl Environ Microbiol 32, 567-571.

De Rosa, M., Gambacorta, A., Nicolaus, B., Chappe, B. \& Albrecht, P. (1983). Isoprenoid ethers; backbone of complex lipids of the archaebacterium Sulfolobus solfataricus. Biochim Biophys Acta 753, 249-256.

Felsenstein, J. (1985). Confidence limits on phylogenies: an approach using the bootstrap. Evolution 39, 783-791.

Franzmann, P. D., Haddad, C. M., Hawkes, R. B., Robertson, W. J. \& Plumb, J. J. (2005). Effects of temperature on the rates of iron and sulfur oxidation by selected bioleaching Bacteria and Archaea: application of the Ratkowsky equation. Miner Eng 18, 1304-1314.

Fuchs, T., Huber, H., Burggraf, S. \& Stetter, K. O. (1996). $16 \mathrm{~S}$ rDNA-based phylogeny of the archaeal order Sulfolobales and reclassification of Desulfurolobus ambivalens as Acidianus ambivalens comb. nov. Syst Appl Microbiol 19, 56-60.
He, Z.-G., Zhong, H. \& Li, Y. (2004). Acidianus tengchongensis sp. nov., a new species of acidothermophilic archaeon isolated from an acidothermal spring. Curr Microbiol 48, 159-163.

Kletzin, A., Urich, T., Müller, F., Bandeiras, T. M. \& Gomes, C. M. (2004). Dissimilatory oxidation and reduction of elemental sulfur in thermophilic archaea. J Bioenerg Biomembr 36, 77-91.

Laska, S., Lottspeich, F. \& Kletzin, A. (2003). Membrane-bound hydrogenase and sulfur reductase of the hyperthermophilic and acidophilic archaeon Acidianus ambivalens. Microbiology 149, 2357-2371.

Ludwig, W., Strunk, O., Westram, R., Richter, L., Meier, H., Yadhukumar, Buchner, A., Lai, T., Steppi, S. \& other authors (2004). ARB: a software environment for sequence data. Nucleic Acids Res 32, 1363-1371.

Mesbah, M., Premachandran, U. \& Whitman, W. B. (1989). Precise measurement of the $\mathrm{G}+\mathrm{C}$ content of deoxyribonucleic acid by highperformance liquid chromatography. Int J Syst Bacteriol 39, 159-167.

Plumb, J. J., Bell, J. \& Stuckey, D. C. (2001). Microbial populations associated with treatment of an industrial dye effluent using an anaerobic baffled reactor. Appl Environ Microbiol 67, 3226-3235.

Plumb, J. J., Gibbs, B., Stott, M. B., Robertson, W. J., Gibson, J. A. E., Nichols, P. D., Watling, H. R. \& Franzmann, P. D. (2002). Enrichment and characterisation of thermophilic acidophiles for the bioleaching of mineral sulphides. Miner Eng 15, 787-794.

Ratkowsky, D. A., Lowry, R. K., McKeekin, T. A., Stokes, A. N. \& Chandler, R. E. (1983). Model for bacterial culture growth rate throughout the entire biokinetic temperature range. J Bacteriol 154, 1222-1226.

Saitou, N. \& Nei, M. (1987). The neighbor-joining method: a new method for reconstructing phylogenetic trees. Mol Biol Evol 4, 406-425.

Segerer, A., Neuner, A. M., Kristjansson, J. K. \& Stetter, K. O. (1986). Acidianus infernus gen. nov., sp. nov., and Acidianus brierleyi comb. nov.: facultatively aerobic, extremely acidophilic thermophilic sulfur-metabolizing archaebacteria. Int J Syst Bacteriol 36, 559-564.

Stetter, K. O. (1989). Order III. Sulfolobales ord. nov. In Bergey's Manual of Systematic Bacteriology, vol. 3, pp. 2250-2253. Edited by J. T. Staley, M. P. Bryant, N. Pfennig \& J. G. Holt. Baltimore: Williams \& Wilkins.

Wilson, A. D. (1960). The micro-determination of ferrous iron in silicate minerals by a volumetric and colorimetric method. Analyst 85, 823-827.

Yoshida, N., Nakasato, M., Ohmura, N., Ando, A., Saiki, H., Ishii, M. \& Igarashi, Y. (2006). Acidianus manzaensis sp. nov., a novel thermoacidophilic Archaeon growing autotrophically by the oxidation of $\mathrm{H}_{2}$ with the reduction of $\mathrm{Fe}^{3+}$. Curr Microbiol 53, 406-411.

Zillig, W., Stetter, K. O., Wunderl, S., Schulz, W., Priess, H. \& Scholz, I. (1980). The Sulfolobus-"Caldariella" group: taxonomy on the basis of the structure of DNA-dependent RNA polymerases. Arch Mikrobiol 125, 259-269.

Zillig, W., Yeats, S., Holz, I., Böck, A., Rettenberger, M., Gropp, F. \& Simon, G. (1986). Desulfurolobus ambivalens, gen. nov., sp. nov., an autotrophic archaebacterium facultatively oxidising or reducing sulfur. Syst Appl Microbiol 8, 197-203. 